\title{
Income Inequality in East Java Province
}

\author{
Nurul Laili Mauliddah ${ }^{1 *}$, Asyidatur Rosmaniar ${ }^{1}$ \\ ${ }^{1}$ Faculty of Economics and Business, University of Muhammadiyah Surabaya, Surabaya, Indonesia \\ ${ }^{*}$ Corresponding author. Email: nurullaili-mauliddah@fe.um-surabaya.ac.id
}

\begin{abstract}
Inequality of income in East Java is still considered high as indicated by the high value of the Gini ratio in most districts / cities. Local government capital expenditure is one of the triggers of the high disparity, in addition to the high per capita spending and open unemployment in East Java. Therefore, this study aims to analyse how influence the capital expenditure, per capita expenditure and unemployment rate have on inequality is implied in the Gini coefficient. Quantitative analysis, explanatory method with panel data. The panel data selection process with data normality test through the estimation of common effect, fixed effect or random effect model parameters and the selection of the right model using panel data regression model which is processed using e-views software 10. The results show the level of income inequality of each district / the city has a moderate stage gap. The Gini index of regency / city in East Java is quite volatile, the highest value is Madiun City, Malang City, Blitar City, and Pasuruan City. Capital expenditure and per capita expenditure have insignificant effect on the gini ratio, while the open unemployment rate partially influences the Gini ratio. Government capital expenditure is realized in the form of expenditure in the education sector, health sector expenditure, goods / services expenditure is no less important than infrastructure spending such as roads, bridges, airports, terminals, ports.
\end{abstract}

Keywords: capital expenditure, per capita expenditure, open unemployment rate, Gini ratio

\section{INTRODUCTION}

The existence of regional autonomy requires each local government to be able to manage the ability of the region for the welfare of society. the government as an agent of development for the welfare of society [1]. Utilization of resources owned by the region to provide facilities for community needs such as infrastructure through government capital expenditure. Government capital expenditure is allocated in the form of provision of transportation facilities, educational infrastructure, and fulfillment of health infrastructure, etc. Different capacities between regions have led to differences in welfare which results in per capita spending which in turn results in inequality of community income. Different infrastructure between districts and cities in East Java triggered the emergence of inequalities.

East Java Province which consists of 28 districts and 9 cities has different characteristics, population and economic potential. Differences in potential and capability between regions indicate a gap both in terms of income and community expenditure. expenditure per capita of the people of East Java Province. Gini Ratio is one model to measure the extent to which inequality connoisseurs of economic growth can be felt by the entire population. The higher the value of the Gini ratio shows the higher level of inequality of an area and shows an uneven distribution of income between high-income and low-income people [2]. In the last 5 years based on Gini data the ratio shows that East Java inequality has increased and decreased in recent years.
Table 1 Gini Ratio of East Java Province 2014-2018

\begin{tabular}{|llllll|}
\hline Gini Ratio & 2014 & 2015 & 2016 & 2017 & 2018 \\
\hline East Java & 0.37 & 0.42 & 0.40 & 0.40 & 0.38 \\
\hline
\end{tabular}

There are areas in East Java that call themselves fertile areas, there are dry areas. That is a designation for regencies / cities that have a number and quality of population and economic potential which is lame. These differences also lead to differences in tax revenues, regional levies, regional own-source revenues and different expenditure budget plans. Capital expenditure is one part of the regional expenditure income budget.

Government policies related to labor in also indicate a gap between districts / cities. The existence of labor market policies has the overall goal of labor market policies is income redistribution, therefore, can be effective in reducing income inequality. Labor market institutions include (1) social protection systems (programs and unemployment benefits, early retirement, systems, and various forms of social income support); (2) various aspects of childbirth (laws on minimum wages, labor protection laws and enforcement law); (3) implementation of active labor market policies, and (4) participation in trade unions and collective bargaining [3].

Referring to BPS data, that East Java Province has a contribution of 30 percent to Indonesia's total national GRDP. Secondary sector and tertiary sector from manufacturing, industry and services / trade. The dominance of the trade, financial, banking and services sectors in the total GRDP of regencies / cities in East Java is concentrated in cities / cities such as Surabaya City, Sidoarjo Regency, Gresik Regency, Pasuruan Regency, Malang Regency, Malang Regency, Kedoj Regency and 
Kediri City. Circulation and accumulation of goods, capital, and services are in the district-city area. Therefore, districts / cities in East Java are interesting to study further. Based on the background above, it is felt that studies are needed: (a) At what stage / level of inequality does income gaps in each district / city in East Java; (b) partial capital expenditure, per capita expenditure and open unemployment rate have an influence on the Gini ratio of regencies / cities in East Java, (c) capital expenditure, per capita expenditure and open unemployment rate together have an influence on the Gini ratio regency / city in East Java.

\section{RESEARCH METHODS}

\subsection{Research Types and Data Sources}

The object studied was 38 regencies / cities from 2010 to 2016. Secondary data sources were obtained from the Central Statistics Agency of East Java Province. Data collected and processed capital expenditure data by the government, per capita expenditure and open unemployment rate as exogenous variables and the value of the Gini index ratio as endogenous variables. Using quantitative analysis, explanatory method with panel data. The process of selecting panel data by conducting a normality test through estimating the parameters of the common effect model, fixed effect or random effect as well as selecting the right model using the Regression Model is processed using e-views 10 . assumption test and interpreting the model chosen exogenous variables affect the endogenous variables.

\subsection{Data Analysis}

This section showed the results of the data analysis used. The analysis used Eviews 10 to choose the best regression model between common effects, fixed effects, and random effects [16].

The multiple linear regression equation model in this research that was done by transforming the regression equation into a logarithmic form. The main purpose of transformation was to change the scale of measurement of the original data into a semi log form, was a form of logarithms used for several independent variables that were positively correlated so that it was easy to test the hypotheses in this study. The equation model was written as follows:

$$
\mathrm{Y}=\alpha+b 1 \mathrm{X} 1+b 2 \mathrm{X} 2+b 3 \mathrm{X} 3+b 4 \mathrm{X} 4+b 5 \mathrm{X} 5+e
$$

The classic assumption test was done as a requirement for processing multiple linear regression data with panel data by using the e-views program 10 . The classic assumption test conducted in this research was the normality test, multicollinearity test, heteroscedasticity test, and autocorrelation test.

\section{RESULTS AND DISCUSSION}

This Gini Ratio is famous for the Lorenz curve which explains how the importance of economic growth is distributed equally to the entire population. At least close to even distribution. Evenly leveling is absolutely not possible, but don't even leave it uneven. [7]relationship between the level of income distribution and the level of economic development takes the form of an inverted U-curve. Beginning with economic development, income distribution will cause higher income inequality, but as the economy matures, the income gap will decrease slowly after passing the peak point.

Do not let economic growth only be enjoyed by a group of people, call it a conglomerate or the bourgeoisie. The government in accordance with Keynesian recommendations must participate in regulating economic activities through regulatory intervention, allocation, distribution and stability of economic resources owned. Government expenditure is one of the expenditure ratios of total regency / city GRDP in East Java. This expenditure consists of education sector expenditure, health sector expenditure, also physical infrastructure expenditure. Although these are all independent factors that can influence the distribution of population income. It is possible that economic growth and population welfare are linked to the distribution of economic growth results with the Gini ratio as the affected factor. Conceptually the framework of the analysis can be described.

The Relationship between Investment and Income Disparity, Harrod-Domar through his theory explains that there is a positive relationship between the level of investment and the pace of the economy, it can be said that lack of investment can reduce the rate of economic growth and low growth per capita[4]. This is because there are no productive economic activities, with the investment discontinuation of a region will experience disparity because natural resources cannot be optimized without any investment that is not received by each region

Harrod-Domar defines capital formation as an important factor that determines economic growth. In theory he said that investment affects economic growth in the long run. It can be concluded that the increase in investment will increase economic growth which is also accompanied by disparities in the opinions of the people, because not every region can receive these investment funds. Each investor will provide regional criteria which according to investors have adequate natural and human resources to benefit the investors. Relationship of Government Expenditures with Income Disparity, Based on Law Number 23 of 2014 one of the objectives of decentralization is to reduce disparity in income between regions with a transfer mechanism and enlarge regional authority to implement development policies that are in accordance with the needs, potential, and owned resources.

The implementation of decentralization each region has the right to take care of all the interests of the region included in the determination of regional government expenditure in the APBN. In accordance with the role of the government in the economy, the government has a stabilizing role, an allocation role, a distribution role, and a dynamics pran. 
Likewise, regional expenditure must be based on these roles.

Descriptively, the Gini ratio in each regency / city in East Java shows that the level of income inequality in the East Java province between each regency / city has a gap at a moderate stage, which is indicated by an average value between $0.2-0,5$ The highest occurred in 2016 of 0.35 . The Gini index of regencies / cities in East Java is quite volatile with the highest value in 2016 even occurring in cities, namely Madiun City 0.42, Malang City and Blitar City 0.41, and Pasuruan City 0.40.

Regression Analysis of Panel Data of Regency / City of East Java Province through the likelihood ratio test obtained a probability value of 0,000 then the fixed effect model is more appropriate to use than the common effect. Followed by the hausman test and obtained a probability of 0,000 or less than the significance value of 0.05 , the random effect model is more appropriate to use than the fixed effect, so that through the exogenous random effect variable approach to endogenous results.

\section{Table 2 Output of random effect analysis}

\begin{tabular}{|c|c|c|c|}
\hline \multicolumn{4}{|c|}{ Dependent Variable: Gini Ratio } \\
\hline Independent & Coefficient & t-stat & Prob. \\
\hline Capital expenditure & 4.040535 & 1.573913 & 0.1167 \\
\hline Per capita expenses & -0.022888 & -4.381633 & 0.0000 \\
\hline TPT & 0.284861 & 3.409685 & 0.0008 \\
\hline R-square & 0.087144 & & \\
\hline Adjust R-square & 0.076692 & & \\
\hline F-stat & 8.337114 & & \\
\hline Prob. F-stat & 0.000026 & & \\
\hline
\end{tabular}

Through the table 2, we get the panel data regression equation; Gini Ratio $=0.076+4.04$ capital expenditure 0.022 expenditure per capita $+0.284 \mathrm{TPT}+\mathrm{e}$. Partial test $(\mathrm{t}$ test) at the 0.05 significance level, if the significance level is below 0.05 then it has a significant effect on the dependent variable. Based on the table II, the probability value of capital expenditure of 0.11 is more than 0.05 , which means that capital expenditure has no significant effect on the Gini ratio [8]. The findings of this study refute previous research that is research from Samuelson [9] and supports research from Kuznet [10] which concludes that public facilities that are the result of government spending have a significant influence on the evenness of the measured income distribution through the Gini ratio. The probability value of per capita expenditure of 0.000 is less than 0.05 , which means that per capita expenditure has a significant effect on the Gini ratio. This result supports research conducted by Monteiro and Turnovsky [11]. Which concludes that government spending has a significant influence on income distribution disparities in the Districts of the Province of Bali. The next variable is the open unemployment rate has a probability of 0.008 less than 0.05 , which means that the open unemployment rate has a significant effect on the Gini ratio. These results indicate support for research from Fauzi [12] which concludes that community per capita income is one of the factors that gives a significant effect on the Gini ratio.

Simultaneous test (F test) from the analysis obtained Fstatistical probability value of 0.000026 or less than 0.05 shows capital expenditure, per capita expenditure, and the level of open unemployment together have an influence on the Gini ratio. From the R-square test it is known that the Rsquare value of 0.087 explains that capital expenditure, per capita expenditure, and open unemployment rate affect the Gini ratio of $8.7 \%$ and the rest is $92 \%$ influenced by other variables not examined in this study.

Capital expenditure, per capita expenditure, and the level of open unemployment have a significant positive effect on the Gini ratio of regencies / cities in East Java, both partially and simultaneously. Even though accumulated the effect is small. This shows that the district / city government in East Java needs to increase the amount in allocating the government budget to the education sector and the health sector and the product / service sector. This supports the theories of economic growth and economic development that have been put forward by previous experts that human development is as important as physical infrastructure development. It even seems that human development needs to be a priority in development. In accordance with the allocation of the state budget for education by 30 percent. Improving education and health can increase innovation and accelerate the transfer of production technology. The existence of technology, production becomes more efficient, increasing the volume and production capacity. In Malthus's theory states that even though the increase in the number of population develops in a series while the production capacity will encourage economic growth in a series of arithmetic [6]. More important how to balance between the two. More precisely the economic growth implemented in the economic development program is more meaningful in equity, proportional justice. The increase in goods and services continues to be increased, but also followed by an increase in the human development index through increased spending on education, health and welfare of the population through disparity in income. Reducing inequality between one another. The Gini ratio is the model. Sufficient population can subsidize disadvantaged populations. The main objective of economic growth is to increase the welfare of the population in various sectors equally.

\section{CONCLUSION}

Based on the results of research and discussion can be concluded that the level of income inequality in each district / city has a moderate stage gap. The Gini index of regency / city in East Java is quite fluctuating, with the highest value being in Madiun City, Malang City, Blitar City, and Pasuruan City. Partially capital expenditure and per capita expenditure each have insignificant influence on the Gini ratio of districts/cities in East Java. While the open unemployment rate has a significant effect on the Gini Ratio of districts/cities in East Java. Capital expenditure, per capita expenditure, and the level of open unemployment together have a significant positive effect on the Gini of the district's ratio in East Java. Gini Ratio is one approach model for economic growth and equitable development through tax instruments and subsidies to the population. Capital expenditures deemed important include infrastructure spending such as roads, bridges, airports, terminals, ports. Education and health sector expenditure is 
[8] M. L. Jhingan, The Economics of Development and Planning, vol. 91. 2006.

[9] L. Samuelson, "Economic theory and experimental economics," J. Econ. Lit., vol. 43, no. 1, pp. 65-107, 2005.

[1] M. Nangarumba, "Analisis Pengaruh Kebijakan Moneter, Kebijakan Fiskal, dan Penyaluran Kredit Terhadap Pertumbuhan Ekonomi di Provinsi Jawa Timur Tahun 2006-2016," J. Ekon. dan Ekon. Stud. Pembang., vol. 8, no. 2, pp. 114-130, 2016.

[2] Q. H. Le and H. N. Nguyen, "The impact of income inequality on economic growth in Vietnam: An empirical analysis," Asian Econ. Financ. Rev., vol. 9, no. 5, pp. 617-629, 2019.

[3] D. Castells-Quintana and V. Royuela, "Unemployment and long-run economic growth: The role of income inequality and urbanisation," Investig. Reg., no. 24, pp. 153-173, 2012.

[4] K. A. A. Putra and S. Arka, "Analisis Pengaruh Tingkat Pengangguran Terbuka , Kesempatan Kerja , Dan Tingkat Pendidikan Terhadap Tingkat Kemiskinan Pada Kabupaten / Kota Di Provinsi Bali," EP Unud, vol. 7, no. 3, pp. 416-444, 2016.

[5] Y. Berman, E. Ben-Jacob, and Y. Shapira, "The dynamics of wealth inequality and the effect of income distribution," PLoS One, vol. 11, no. 4, 2016.

[6] Obadić, N. Šimurina, and R. Sonora, "The effects of tax policy and labor market institutions on income inequality," Zb. Rad. Ekon. Fak. au Rijeci, vol. 32, no. 1, pp. 121-140, 2014.

[7] M. P. Todaro, Pembangunan Ekonomi di Dunia Ketiga Edisi keempat Jilid I. 1994.
[10] S. Kuznet, "Growth and Income Inequality," Am. Econ. Rev., vol. 45, no. 1, pp. 1-28, 1955.

[11] G. Monteiro and S. J. Turnovsky, "The composition of productive government expenditure," Indian Growth Dev. Rev., vol. 1, no. 1, pp. 57-83, 2008.

[12] Azka Fauzia and D. Aji Suseno, “Analisis Determinan Disparitas Pendapatan di Kawasan Purwomanggung Tahun 2009-2015," Econ. Dev. Anal. J., vol. 6, no. 4, pp. 436-444, 2018.

[13] Badan Pusat Statistik. (2010-2017). Jawa Timur Dalam Angka.

[14] Fatihudin, D., Jusni and M. Mochklas, 2018, How Measuring Financial Performance, International Journal of Civil Engineering and Technology (IJCIET), 9(6):553-557

[15] Mochklas, M., Panggayudi, D.S., \& Soenarto. 2019. The Work Culture of South Korean Companies In Indonesia. Humanities \& Social Sciences Reviews, 7(4):603-60. https://doi.org/10.18510/hssr.2019.7480

[16] Nuryanto \& Pambuko, Z. B. (2018). Eviews untuk Analisis Ekonometrika Dasar: Aplikasi dan Interpretasi. Magelang: Unimma Press. 